\title{
Modification of vasodilator response in streptozotocin-induced diabetic rat
}

\author{
J ean-François Bouchard, Éric C. Dumont, and Daniel Lamontagne
}

\begin{abstract}
Functional dilatory response in streptozotocin-induced diabetic rats was investigated using thoracic aortas, isolated hearts, and mesenteric beds. Dose-response curves to the $\mathrm{PGI}_{2}$ analogue iloprost on phenylephrinepreconstricted rings of diabetic rats and controls were comparable. In contrast, decreased vasodilation in diabetic rats was observed when dose-response curves to iloprost were performed in hearts and on phenylephrine-preconstricted mesenteric beds. Dose-response curves to forskolin, an adenylyl cyclase activator, performed with hearts and phenylephrine-preconstricted aortic rings and isolated mesenteric beds of diabetic rats and controls were comparable. However, a decreased vasodilation to the ATP-sensitive potassium channel $\left(\mathrm{K}_{\mathrm{ATP}}\right)$ activator lemakalim was observed in diabetic hearts, but not in aortic rings and mesenteric beds. In conclusion, under our experimental conditions, diabetes mellitus affects the vasodilation to iloprost in both coronary and mesenteric beds, but not in the aorta. In the heart, this modification of vascular reactivity may be due to a decrease in $\mathrm{K}_{\mathrm{ATP}}$ channel mediated response and not to a decreased activity of adenylyl cyclase. At this time, in the isolated mesenteric bed, the mechanism of this modification in vascular reactivity remains unknown.
\end{abstract}

Key words: diabetes mellitus, iloprost, $\mathrm{K}_{\mathrm{ATP}}$ channels, adenylyl cyclase, aorta, coronary circulation, mesenteric bed.

Résumé : On a examiné la réponse dilatatrice fonctionnelle chez des rats rendus diabétiques par l'administration de streptozotocine, en utilisant des aortes thoraciques, des coeurs isolés et des lits mésentériques. Les courbes doseréponse à l'analogue des $\mathrm{PGI}_{2}$, iloprost, sur des anneaux précontractés au moyen de phényléphrine ont été comparables chez les rats diabétiques et témoins. À l'opposé, les courbes dose-réponse à l'iloprost obtenues dans les coeurs et les lits mésentériques précontractés par la phényléphrine ont montré une diminution de la vasodilatation chez les rats diabétiques. Les courbes dose-réponse à la forskoline, un activateur d'adénylcyclase, ont été comparables dans les coeurs et les anneaux aortiques précontractés par la phényléphrine ainsi que dans les lits mésentériques isolés des rats diabétiques et témoins. Toutefois, la vasodilatation induite par l'activateur des canaux potassiques sensibles à l'ATP $\left(\mathrm{K}_{\mathrm{ATP}}\right)$, lemakalin, a été diminuée dans les coeurs, mais pas dans les anneaux aortiques ni dans les lits mésentériques diabétiques. Ainsi, dans nos conditions expérimentales, le diabète sucré influe sur la vasodilatation induite par l'iloprost dans les lits mésentériques et coronariens, mais pas dans l'aorte. Dans le coeur, cette modification de la réactivité vasculaire pourrait être due à une diminution de la réponse véhiculée par les canaux $\mathrm{K}_{\mathrm{ATP}}$ et non à une diminution de l'activité de l'adénylcyclase. Pour le moment, le mécanisme de cette modification dans le lit mésentérique n'est pas connu.

Mots clés : diabète sucré, iloprost, canaux $\mathrm{K}_{\mathrm{ATP}}$, adénylcyclase, aorte, circulation coronaire, lit mésentérique.

[Traduit par la Rédaction]

\section{Introduction}

Cardiovascular diseases such as atherosclerosis, microangiopathy, and congestive heart failure are more prevalent in diabetic subjects (Garcia et al. 1974; Jarrett 1989). These diseases could lead to diabetic complications including neuropathy, retinopathy, nephropathy, and increase in mortality and morbidity from cardiovascular disorders (Garcia et al. 1974; Jarrett 1989; Tooke 1989). Consequently, there has been much interest in the etiology of cardiovascular disorders associated with this disease, and hence animal models

Received February 1, 1999.

J.-F. Bouchard, É.C. Dumont, and D. Lamontagne. ${ }^{1}$

Faculté de pharmacie, Université de Montréal, C.P. 6128, Succursale Centre-ville, Montréal, QC H3C 3J7, Canada.

${ }^{1}$ Author for correspondence

(e-mail: daniel.lamontagne@umontreal.ca). like alloxan or streptozotocin-induced (STZ) diabetes have been developed.

Rats treated with STZ display many features seen in human subjects with uncontrolled diabetes mellitus, including hyperglycemia, polydipsia, polyuria, and impaired weight gain (Hebden et al. 1986; Tomlinson et al. 1989). Most of the usual diabetes mellitus complications can be observed in this model, including vascular diseases (Tomlinson et al. 1992).

STZ treatment results in changes in vascular reactivity to both vasoconstrictors and endothelium-dependent vasodilator agents (Tomlinson et al. 1992). These changes have been observed in different vessels, including aorta (Ramanadham et al. 1984), mesenteric (Takiguchi et al. 1989), cerebral arterioles (Mayhan 1992; Mayhan 1994a), tail arteries (Ramanadham et al. 1984), as well as in perfused kidneys (Sarubbi et al. 1989). However, little is known about coronary vessels and endothelium-independent vasodilators. 
Prostacyclin $\left(\mathrm{PGI}_{2}\right)$, an endogenous autacoid synthesized in coronary circulation from arachidonic acid by cyclooxygenase (Needleman et al. 1986; Bouchard et al. 1994), mediates vascular smooth muscle relaxation through its action on specific membrane receptors, IP receptors (Campbell and Halushka 1996). Following activation of IP receptors, smooth muscle relaxation may be mediated by two intracellular signalling pathways: production of cyclic AMP by adenylyl cyclase (Needleman et al. 1986; Campbell and Halushka 1996) and activation of ATP-sensitive potassium channels ( $\mathrm{K}_{\mathrm{ATP}}$ channels) (Jackson et al. 1993). The contribution of $\mathrm{K}_{\mathrm{ATP}}$ channels in the vasodilation to endogenous $\mathrm{PGI}_{2}$, as well as the stable analogue of $\mathrm{PGI}_{2}$, iloprost, was confirmed in the isolated rat heart by the inhibitory effect of glibenclamide, a selective $\mathrm{K}_{\mathrm{ATP}}$ channel blocker (Bouchard et al. 1994).

It has been reported that $\mathrm{K}_{\text {ATP }}$ channel currents could be altered by STZ-induced diabetes mellitus in aorta (Kamata et al. 1989), cerebral arterioles (Mayhan and Faraci 1993), ventricular myocytes (Shimoni et al. 1994), and pancreatic $\beta$-cells (Tsuura et al. 1992). In addition, decreased activity of adenylyl cyclase in the sciatic nerve (Shindo et al. 1993) and decreased sensitivity of adenylyl cyclase to forskolin in the cerebrum capillaries (Palmer et al. 1983) have been observed in STZ-induced diabetes.

The first aim of the present study was therefore to evaluate whether STZ-induced diabetes produces changes in vascular reactivity to iloprost, a stable analogue of $\mathrm{PGI}_{2}$. The second aim was to identify the intracellular signalling pathways affected by STZ-induced diabetes. The experiments were made simultaneously with isolated hearts, thoracic aortic rings, and isolated mesenteric beds, in order to compare the coronary circulation with a large conduit artery and with a resistance vascular bed. A preliminary report has been published previously (Bouchard et al. 1997).

\section{Methods}

\section{Rat preparation}

The investigation was performed in accordance with the guidelines from the Canadian Council on Animal Care. Male SpragueDawley rats weighing 200-225 g were made diabetic or treated as vehicle control by injection into the tail vein of STZ $\left(55 \mathrm{mg} \mathrm{kg}^{-1}\right)$ or vehicle ( $0.1 \mathrm{~N}$ citrate buffer, $\mathrm{pH} 4.5)$, respectively, under light anesthesia (methoxyflurane). Animals were allowed free access to food and water at all times. After 2 months, diabetic rats and agematched controls were narcotized with $\mathrm{CO}_{2}$ until complete loss of consciousness and promptly decapitated. Body weight and blood glucose levels (One Touch II glucometer, Lifescan Canada Ltd., Burnaby, B.C.) were measured at the time of decapitation.

\section{Buffer}

The normal solution consisted of a modified Krebs-Henseleit buffer containing (in $\mathrm{mM}$ ) NaCl, $118 ; \mathrm{KCl}, 4 ; \mathrm{CaCl}_{2}, 2.5 ; \mathrm{KH}_{2} \mathrm{PO}_{4}$, $1.2 ; \mathrm{MgSO}_{4}, 1 ; \mathrm{NaHCO}_{3}, 24$; and either D-glucose, 11, for aortas and mesenteric beds, or D-glucose, 5, and pyruvate, 2, for hearts. The solution was gassed with $95 \% \mathrm{O}_{2}-5 \% \mathrm{CO}_{2}(\mathrm{pH} 7.4)$ and kept at a constant temperature of $37^{\circ} \mathrm{C}$.

\section{Heart preparation}

The thorax was rapidly opened and the heart excised and immersed in ice-cold heparinized buffer $\left(10 \mathrm{IU} \cdot \mathrm{mL}^{-1}\right)$. It was immediately mounted on the experimental setup and perfused at constant flow by means of a digital roller pump. A 20-mL compliance chamber along the perfusion line ensured a continuous flow. The flow rate was adjusted during the stabilization period to obtain a coronary perfusion pressure of approximately $75 \mathrm{mmHg}(1 \mathrm{mmHg}$ $=133.3 \mathrm{~Pa}$ ) and was held constant thereafter. Flow rate was continuously measured with an in-line ultrasonic flow probe and meter (model T106, Transonic Systems Inc., Ithaca, N.Y.). Perfusion pressure was monitored to calculate coronary resistance. All drugs were perfused through a Y-connector in the aortic cannula with syringe pumps (model 11, Harvard Apparatus, South Natick, Mass.) at one-hundredth of the coronary flow rate. Adequate mixing of the drugs was ensured by the turbulent flow created in the reverse drop shaped aortic cannula. All concentrations mentioned in the text and figures refer to the final concentration after mixing. Coronary perfusion pressure was measured with a pressure transducer connected to a side arm of the aortic perfusion cannula. Isovolumetric left ventricular pressure and its first derivative $(\mathrm{d} P / \mathrm{d} t)$ were measured by a fluid-filled latex balloon inserted into the left ventricle and connected to a second pressure transducer. The volume of the balloon was adjusted to obtain a diastolic pressure between 5 and $10 \mathrm{mmHg}$. Heart rate was derived from the left ventricular pressure trace by a tachograph. Data were recorded on a polygraph system (Grass model 79, Astro-Med Inc., West Warwick, R.I.)

\section{Aortic ring preparation}

Thoracic aortas were carefully excised, cleaned of all fat and connective tissue, and cut into 4-mm rings. Endothelium was removed in some preparations by inserting one arm of a fine forceps into the lumen and rolling back and forth 10 times on a gauze soaked with physiological solution. The preparations were then connected to a strain gauge (Grass FT03), and isometric tension was recorded on a data acquisition system (BIOPAC Systems, Santa Barbara, Calif.). The preparations were stretched to an optimal $4 \mathrm{~g}$ resting tension, as determined with repeated $20 \mathrm{mM} \mathrm{KCl}$ contractions. In preparations in which endothelial cells were removed, the addition of $1 \mu \mathrm{M}$ acetylcholine to $\mathrm{KCl}(20 \mathrm{mM})$ preconstricted rings did not induce any relaxation. The preparations were allowed to stabilize for $30 \mathrm{~min}$ before resuming the experimentation. Each ring was used for a single dose-response curve.

\section{Mesenteric preparation}

Following the decapitation, the superior mesenteric artery was rapidly cannulated and perfused in situ with a blunted hypodermic needle at its aortic origin. The whole mesenteric bed was separated from the intestine at the intestinal border and supported on a Buchner funnel. The preparation was perfused at a constant flow rate of $4 \mathrm{~mL} \cdot \mathrm{min}^{-1}$ by a peristaltic pump with Krebs solution as described above. Vascular responses were measured as changes in perfusion pressure (in $\mathrm{mmHg}$ ), using pressure transducers, and recorded on a polygraph system (Grass model 79 polygraph). A 60min stabilization period was allowed before the experiments were started. As described with isolated hearts, all drugs were perfused through a Y-connector in the feeding cannula with syringe pumps (model 11, Harvard Apparatus) at one-hundredth of the mesenteric flow rate.

\section{Experimental protocols}

To investigate possible changes in vascular reactivity to iloprost in diabetic rats, a cumulative dose-response curve to this agent $(1 \mathrm{nM}-0.1 \mu \mathrm{M})$ was performed in hearts of diabetic rats and agematched controls. Each concentration of iloprost was perfused until a steady state was obtained (between 5 and $10 \mathrm{~min}$ ), followed by perfusion of the next concentration with no washout between concentrations.

Additional dose-response curves were performed to study the components of the signalling pathways involved in the vasodilation to iloprost. To assess changes in the activity of adenylyl cyclase, 
Fig. 1. Changes in coronary resistance with increasing concentrations of (A) iloprost, (B) forskolin, and (C) lemakalim in hearts from diabetic $(\triangle)$ and control $(\bigcirc)$ rats. *Significantly different fitted plateau.
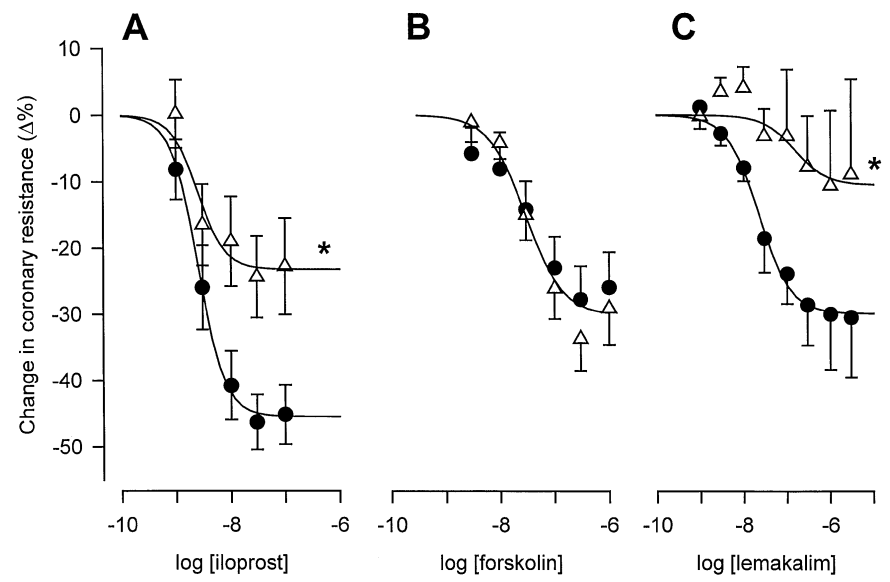

dose-response curves to forskolin $(1 \mathrm{nM}-3 \mu \mathrm{M})$ were performed in diabetic hearts and age-matched controls. Likewise, the $\mathrm{K}_{\mathrm{ATP}}$ channel mediated response was investigated with dose-response curves to lemakalim $(1 \mathrm{nM}-3 \mu \mathrm{M})$. These dose-response curves were performed as described for iloprost. In some preparations, single boluses of serotonin $(10 \mu \mathrm{M})$ and sodium nitroprusside $(3 \mu \mathrm{M})$ were also tested.

To compare the coronary resistance arteries with a large conduit artery, dose-response curves to iloprost $(10 \mathrm{pM}-3 \mu \mathrm{M})$, forskolin $(10 \mathrm{pM}-10 \mu \mathrm{M})$, and lemakalim $(10 \mathrm{pM}-10 \mu \mathrm{M})$ were performed in phenylephrine-preconstricted aortic rings $(0.3 \mu \mathrm{M}$ and $30 \mathrm{nM}$ in intact and endothelium-denuded rings, respectively) of diabetic rats and controls.

To compare the coronary bed with another resistance bed, cumulative dose-response curves to iloprost $(1 \mathrm{nM}-1 \mu \mathrm{M})$, forskolin $(1 \mathrm{nM}-3 \mu \mathrm{M})$, and lemakalim $(1 \mathrm{nM}-10 \mu \mathrm{M})$ were performed in $30 \mu \mathrm{M}$ phenylephrine-preconstricted mesenteric beds of diabetic rats and controls. Each concentration of agent was perfused until a steady state was obtained $(10 \mathrm{~min})$, followed by perfusion of the next concentration with no washout between concentrations.

\section{Statistical analysis}

Values are given as means \pm SEM. Dose-response curves that exhibited sigmoid shape were analyzed using a curve-fitting analysis program (De Léan et al. 1978). This program allows the estimation of parameters, such as $\mathrm{EC}_{50}$, maximum response, and slope factor, and statistical comparison of several dose-response curves. Only probability values $(p)$ smaller than 0.05 were considered to be statistically significant.

\section{Drugs}

Iloprost was a gift from Berlex Canada. Lemakalim was a gift from SmithKline Beecham. All other drugs were obtained from Sigma-Aldrich Canada Ltd. (Oakville, Ont.). A stock solution of iloprost, $10 \mathrm{mM}$, was prepared in Krebs-Henseleit buffer and carefully kept at $4^{\circ} \mathrm{C}$ until use. All drugs were prepared as $10 \mathrm{mM}$ stock solutions in Krebs-Henseleit buffer, with the following exceptions: forskolin was dissolved in dimethyl sulfoxide (DMSO), and lemakalim in $70 \%$ ethanol. Final concentrations of DMSO in both coronary and mesenteric circulation and in aortic rings were 0.03 and $0.1 \%$, respectively, and did not induce any effect. Ethanol
Fig. 2. Changes in tension with increasing concentrations of (A) iloprost, (B) forskolin, and (C) lemakalim in intact aortic rings from diabetic $(\triangle)$ and control $(\bigcirc)$ rats.
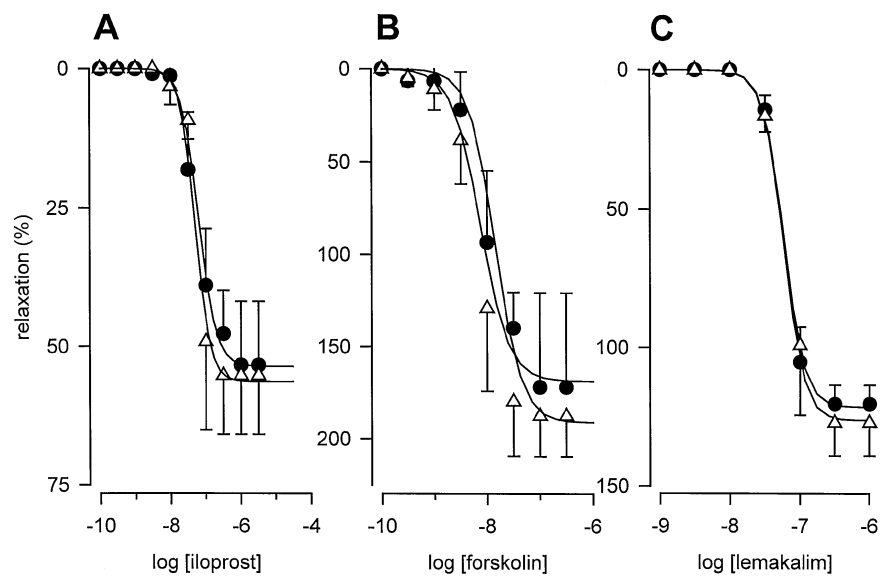

at 0.02 and $0.7 \%$ in both coronary and mesenteric circulation and in aortic rings, respectively, did not produce any effect. Subsequent dilutions were made in Krebs-Henseleit buffer.

\section{Results}

A total of 30 nondiabetic rats and 33 diabetic rats were used in the present study. Body weight of rats treated with STZ or vehicle 2 months after injection was $364 \pm 9$ and 561 $\pm 13 \mathrm{~g}$, respectively, $p<0.05$. The blood glucose level of these animals was $26.0 \pm 0.6$ and $4.0 \pm 0.1 \mathrm{mmol} \cdot \mathrm{L}^{-1}$, respectively $(p<0.05)$.

\section{Coronary circulation}

Coronary flow rate of nondiabetic hearts $(n=18)$ was $6.77 \pm 0.43 \mathrm{~mL} \cdot \mathrm{min}^{-1} \cdot \mathrm{g}^{-1}$, for a mean heart weight of $2.34 \pm$ $0.10 \mathrm{~g}$. In diabetic hearts $(n=18)$, coronary flow rate was $6.82 \pm 0.48 \mathrm{~mL} \cdot \mathrm{min}^{-1} \cdot \mathrm{g}^{-1}$, for a mean heart weight of $2.19 \pm$ 0.14 g. Perfusion of iloprost induced a dose-dependent vasodilation in both diabetic and age-matched control hearts (Fig. 1). However, in diabetic hearts, the maximal response to iloprost was reduced by half compared with control hearts, whereas sensitivity was found to be comparable in the two groups $\left(\log \mathrm{EC}_{50}=-8.6 \pm 0.1\right.$ for both diabetic and control hearts, $n=6$ per group).

Adenylyl cyclase activation with forskolin induced a similar decrease in coronary resistance in both diabetic and control hearts (Fig. 1), with a comparable sensitivity $\left(\log \mathrm{EC}_{50}=\right.$ $-7.5 \pm 0.1, n=6$ per group).

Coronary resistance decreased with lemakalim $(0.3 \mathrm{nM}-$ $3 \mu \mathrm{M}$ ) in a dose-dependent fashion (Fig. 1). Comparable sensitivity to lemakalim was observed in both diabetic and control hearts $\left(\log \mathrm{EC}_{50}=-7.3 \pm 0.3, n=6\right)$. However, the maximal response produced by lemakalim in diabetic hearts was diminished, compared with that of control hearts (Fig. 1).

To confirm that the reduction in dilator response was specific to $\mathrm{K}_{\mathrm{ATP}}$ channel activators, additional vasodilators were tested. The response to the endothelium-dependent dilator 
Fig. 3. Changes in tension with increasing concentrations of (A) iloprost, (B) forskolin, and (C) lemakalim in endotheliumdenuded aortic rings from diabetic $(\triangle)$ and control $(\bullet)$ rats.

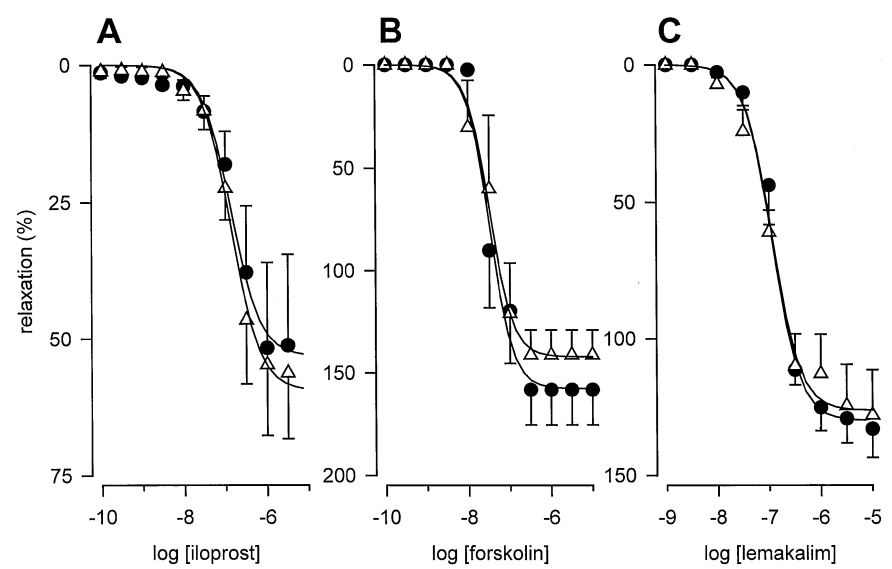

serotonin $(-25.2 \pm 4.8$ vs. $-25.1 \pm 3.2 \%$ change in coronary resistance, $n=8, p>0.05)$ and to the endothelium-independent dilator sodium nitroprusside $(-30.0 \pm 5.5$ vs. $-30.0 \pm 3.8 \%$ change in coronary resistance, $n=8, p>0.05$ ) was found to be unaltered in diabetic hearts.

\section{Aortic rings}

Phenylephrine was used to increase tone in aortic rings before the dose-response curves to the dilator agents. Comparable sensitivity $\left(\log \mathrm{EC}_{50}=-7.23 \pm 0.08\right.$ and $-6.96 \pm$ 0.07 , respectively, $n=6, p=0.06$ ) and maximal response $(3.19 \pm 0.09$ and $3.27 \pm 0.11 \mathrm{~g}$, respectively, $n=6, p=$ $0.109)$ were observed in intact rings from diabetic and control rats. Similar results were observed in endotheliumdenuded preparations (data not shown).

Phenylephrine-preconstricted aortic rings, either intact (Fig. 2) or endothelium denuded (Fig. 3), relaxed to iloprost, forskolin, and lemakalim in a dose-dependent fashion. No significant difference was observed in either sensitivity or maximal response between diabetic and control aortas, either in the presence (Fig. 2) or in the absence (Fig. 3) of the endothelium.

\section{Mesenteric circulation}

Perfusion of iloprost induced a dose-dependent vasodilation in both diabetic and age-matched control mesenteric beds (Fig. 4). However, in diabetic mesenteric beds, the maximal response to iloprost was reduced by half compared with control mesenteric beds, whereas sensitivity was comparable in the two groups $\left(\log \mathrm{EC}_{50}=-7.4 \pm 0.4\right.$ for both diabetic and control mesenteric beds, $n=6$ per group).

Adenylyl cyclase activation with forskolin induced a similar decrease in coronary resistance in both diabetic $(n=6)$ and control $(n=4)$ mesenteric beds (Fig. 4), with a comparable sensitivity $\left(\log \mathrm{EC}_{50}=-7.4 \pm 0.1\right)$.

Mesenteric resistance decreased with lemakalim in a dose-dependent fashion (Fig. 4). Comparable sensitivity to lemakalim was observed in both diabetic and control
Fig. 4. Changes in mesenteric resistance with increasing concentrations of (A) iloprost, (B) forskolin, and (C) lemakalim in hearts from diabetic $(\triangle)$ and control $(\bigcirc)$ rats. *Significantly different fitted plateau.
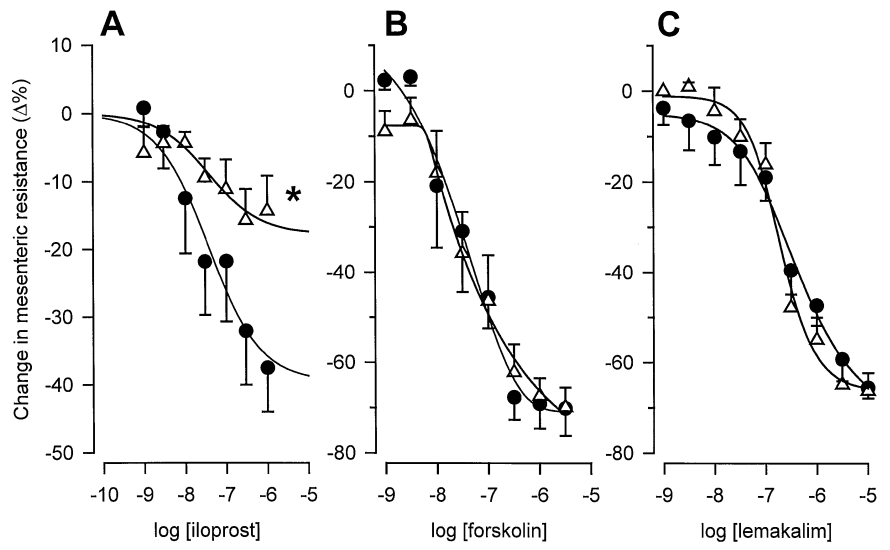

mesenteric beds $\left(\log \mathrm{EC}_{50}=-6.6 \pm 0.1, n=3\right.$ per group). The maximal response produced by lemakalim in diabetic mesenteric beds was not significantly different from that of controls (Fig. 4).

\section{Discussion}

In the present study, we evaluated the vascular reactivity to iloprost in both the coronary and mesenteric beds and with a typical conductance artery (aorta) of STZ-induced diabetic rats. The intracellular signalling pathways affected by diabetes were also evaluated. The two major findings of the present study were (i) STZ-induced diabetes affects the coronary and the mesenteric vasodilation to iloprost and (ii) decreased activity of $\mathrm{K}_{\mathrm{ATP}}$ channels and not adenylyl cyclase explains the reduced vasodilation to iloprost observed in coronary circulation. At this time, in the isolated mesenteric bed, the mechanism of this modification in vascular reactivity remains unknown.

\section{Effect of diabetes mellitus on iloprost vasodilation}

In our experimental conditions, we found that thoracic aorta and mesenteric and coronary circulation from the same animal are affected differently: diabetes reduced the dilator response to iloprost in the coronary and the mesenteric beds but not in the aorta. The effect of STZ-induced diabetes on vascular responses has been extensively studied, most often in the mesenteric bed and with the aorta (for a review see Tomlinson et al. 1992). Little is known on the effect of diabetes on the coronary circulation, and no study has compared the coronary bed with the aorta or the mesenteric bed from the same animal. The reason why STZ-induced diabetes affects the vascular beds differently remains elusive. Although highly speculative, differences in metabolic activity or a different vulnerability to oxidative stress and (or) advanced glycation end products may provide a plausible explanation. Obviously, additional experiments are needed to address this 
question. However, our data clearly show that it may be hazardous to extrapolate results obtained with large conductance arteries such as the aorta to other vascular beds.

Alterations in the vascular response to iloprost can be explained by changes in the signalling pathways downstream of receptor activation. This was assessed in the present study, using forskolin and lemakalim. On the other hand, alterations in $\mathrm{PGI}_{2}$ receptors or G-proteins may also contribute to the blunted response to iloprost. Interestingly, there are some reports on the effect of diabetes on platelet IP receptors. For example, Modesti et al. (1991) reported that platelet $\mathrm{PGI}_{2}$ receptor changes are not detectable in diabetic patients, but could take place when platelet lipid composition is altered. Shepherd et al. (1983) reported that the hyperaggregability of diabetic platelets is not due to any alteration in platelet IP receptor numbers or affinity. To the best of our knowledge, no studies have assessed alterations in IP receptors during diabetes in vascular tissues. Therefore, this question remains unanswered.

\section{Effect of diabetes mellitus on adenylyl cyclase signalling pathway}

Some have reported a decreased activity of adenylyl cyclase in the sciatic nerve (Shindo et al. 1993) as well as a decreased sensitivity of adenylyl cyclase to forskolin in the capillaries of the cerebrum (Palmer et al. 1983) in STZinduced diabetes. However, these findings are not without controversy. Other groups have found that adenylyl cyclase activity in seminal vesicle (Rodriguez-Pena et al. 1994) or in cerebral arterioles (Mayhan 1994b) remained unchanged in spite of diabetes.

The results of our study are in accordance with the latter: we found that the response to forskolin in the aorta, in the mesenteric circulation, and in the coronary bed is not affected by diabetes 2 months after injection of STZ.

\section{Effect of diabetes mellitus on $K_{\mathrm{ATP}}$ channels}

Two previous studies have addressed the effects of diabetes mellitus on vascular changes in response to activation of $\mathrm{K}_{\mathrm{ATP}}$ channels (Kamata et al. 1989; Mayhan and Faraci 1993). Kamata et al. (1989) measured relaxation of the thoracic aorta to cromakalim in vitro, whereas Mayhan and Faraci (1993) evaluated vasodilation of cerebral arterioles to RP52891 in vivo. Relaxation of the cerebral arterioles and thoracic aorta from diabetic rats was significantly impaired compared with age-matched controls. Furthermore, others have reported that $\mathrm{K}_{\text {ATP }}$ current could be altered by STZ-induced diabetes mellitus in ventricular myocytes (Shimoni et al. 1994) and pancreatic $\beta$-cells (Tsuura et al. 1992). Thus, it appears that STZ-induced diabetes mellitus can alter the functional response of $\mathrm{K}_{\mathrm{ATP}}$ channels in many tissues.

According to these studies, we found that, 2 months after injection of STZ, responses to lemakalim in thoracic aorta or in the mesenteric bed and coronary circulation are affected differently: diabetes reduced the dilator response to lemakalim in the coronary bed but not in the aorta or in the mesenteric bed. We have previously reported that glibenclamide, a $\mathrm{K}_{\mathrm{ATP}}$ channel blocker, reduces the dilator response to iloprost in the coronary bed, but not in the aorta (Bouchard et al. 1994) and in the mesenteric bed (unpublished observations). Therefore, the impaired response to lemakalim suggests that an impaired activity of $\mathrm{K}_{\mathrm{ATP}}$ channels could account for the reduced coronary response to iloprost in diabetes.

On the other hand, we cannot rule out that the reduced response to lemakalim is due to a decreased ability of coronary smooth muscle to relax in response to potassium channel opening. $\mathrm{K}_{\mathrm{ATP}}$ channel openers produce smooth muscle relaxation through hyperpolarization, which in turn reduces calcium influx through voltage-gated calcium channels. Therefore, a reduced calcium influx through these channels could, theoretically, impair the response to $\mathrm{K}_{\text {ATP }}$ channel openers. This hypothesis is supported by the fact that receptor-mediated coronary vasoconstriction with vasopressin and angiotensin II, which act partially through nifedipine-sensitive calcium influx, is also reduced in these hearts (unpublished observation).

In our experimental conditions, coronary vasodilation to sodium nitroprusside and serotonin were not impaired by STZ-induced diabetes. Thus, altered coronary vasodilation to lemakalim cannot be attributed to a nonspecific impairment of vascular smooth muscle relaxation in diabetic rats. The mechanism involved in this altered response of coronary arteries to $\mathrm{K}_{\mathrm{ATP}}$ channel activator is unknown, and the following possibilities remain purely speculative. First, it is possible that STZ-induced diabetes mellitus causes a decrease in the sensitivity and (or) in the number of $\mathrm{K}_{\text {ATP }}$ channels. Diabetes may also produce changes in membrane potential, changes in $\mathrm{Na}^{+}-\mathrm{K}^{+}$ATPase activity (Ohara et al. 1991), and (or) general changes in membrane structure and composition. This could partially explain the different coronary vascular reactivity to lemakalim in diabetic rats. The reason why the aorta and the mesenteric bed are not affected remains unknown.

In conclusion, the results of our study show that maximum dilation to iloprost is decreased in the coronary and the mesenteric beds but not in the aorta. In the coronary circulation, the reduced vasodilation to iloprost may be attributed to a decrease in $\mathrm{K}_{\mathrm{ATP}}$ channel mediated response and not to a modification in adenylyl cyclase activity. However, at present, in the isolated mesenteric bed, the mechanism of this modification in vascular reactivity remains unknown.

\section{Acknowledgements}

This project was supported by a grant from the Canadian Diabetes Association. J.F.B. held a studentship from the Fonds de la recherche en santé du Québec and from Novartis Pharma Canada. E.C.D. held a studentship from FCARFRSQ-santé.

\section{References}

Bouchard, J.-F., Dumont, E., and Lamontagne, D. 1994. Evidence that prostaglandins $\mathrm{I}_{2}, \mathrm{E}_{2}$, and $\mathrm{D}_{2}$ may activate ATP sensitive potassium channels in the isolated rat heart. Cardiovasc. Res. 28: 901-905.

Bouchard, J.-F., Dumont, E.C., and Lamontagne, D. 1997. Diminution de la réponse vasculaire à l'iloprost chez le rat diabétique. Arch. Mal. Coeur, 90: 1071-1074.

Campbell, W.B., and Halushka, P.V. 1996. Lipid-derived autacoids: eicosanoids and platelet-activating factor. In Goodman and Gilman's The pharmacological basis of therapeutics. 9th ed. 
Edited by J.G. Hardman, L.E. Limbird, P.B. Molinoff, R.W. Ruddon, and A. Goodman Gilman. McGraw-Hill, New York. pp. 601-616.

De Léan, A., Munson, P.J., and Rodbard, D. 1978. Simultaneous analysis of families of sigmoidal curves: application to bioassay, radioligand assay, and physiological dose-response curves. Am. J. Physiol. 235: E97-E102.

Garcia, M.J., McNamara, P.M., Gordon, T., and Kannel, W.B. 1974. Morbidity and mortality in diabetics in the Framingham population. Sixteen year follow-up study. Diabetes, 23: 105-111.

Hebden, R.A., Gardiner, S.M., Bennett, T., and MacDonald, I.A. 1986. The influence of streptozotocin-induced diabetes mellitus on fluid and electrolyte handling in rats. Clin. Sci. 70: 111-117.

Jackson, W.F., König, A., Dambacher, T., and Busse, R. 1993. Prostacyclin-induced vasodilation in rabbit heart is mediated by ATP-sensitive potassium channels. Am. J. Physiol. 264: H238$\mathrm{H} 243$.

Jarrett, R.J. 1989. Cardiovascular disease and hypertension in diabetes mellitus. Diabetes Metab. Rev. 5: 547-558.

Kamata, K., Miyata, N., and Kasuya, Y. 1989. Functional changes in potassium channels in aortas from rats with streptozotocininduced diabetes. Eur. J. Pharmacol. 166: 319-323.

Mayhan, W.G. 1992. Impairment of endothelium-dependent dilatation of the basilar artery during diabetes mellitus. Brain Res. 580: 297-302.

Mayhan, W.G. 1994a. Effect of diabetes mellitus on response of the basilar artery to activation of ATP-sensitive potassium channels. Brain Res. 636: 35-39.

Mayhan, W.G. 1994b. Responses of cerebral arterioles to activation of beta-adrenergic receptors during diabetes mellitus. Stroke, 25: $141-146$.

Mayhan, W.G., and Faraci, F.M. 1993. Responses of cerebral arterioles in diabetic rats to activation of ATP-sensitive potassium channels. Am. J. Physiol. 265: H152-H157.

Modesti, P.A., Fortini, A., Gensini, G.F., Vanni, D., Prisco, D., and Abbate, R. 1991. Human prostacyclin platelet receptors in diabetes mellitus. Thromb. Res. 63: 541-548.

Needleman, P., Turk, J., Jakschik, B.A., Morrison, A.R., and Lefkowith, J.B. 1986. Arachidonic acid metabolism. Annu. Rev. Biochem. 55: 69-102.

Ohara, T., Sussman, K.E., and Draznin, B. 1991. Effect of diabetes on cytosolic free $\mathrm{Ca} 2+$ and $\mathrm{Na}(+)-\mathrm{K}(+)$-ATPase in rat aorta. Diabetes, 40: 1560-1563.
Palmer, G.C., Wilson, G.L., and Chronister, R.B. 1983. Streptozotocin-induced diabetes produces alterations in adenylate cyclase in rat cerebrum, cerebral microvessels and retina. Life Sci. 32: 365-374.

Ramanadham, S., Lyness, W.H., and Tenner, T.E., Jr. 1984. Alterations in aortic and tail artery reactivity to agonists after streptozotocin treatment. Can. J. Physiol. Pharmacol. 62: 418-423.

Rodriguez-Pena, M.S., Guijarro, L.G., Juarranz, M.G., RodriguezHenche, N., Bajo, A.M., Aguado, F., and Prieto, J.C. 1994. Analysis of vasoactive intestinal peptide receptors and the $\mathrm{G}$ protein regulation of adenylyl cyclase in seminal vesicle membranes from streptozotocin-diabetic rats. Cell. Signalling, 6: 147-156.

Sarubbi, D., McGiff, J.C., and Quilley, J. 1989. Renal vascular responses and eicosanoid release in diabetic rats. Am. J. Physiol. 257: F762-F768.

Shepherd, G.L., Lewis, P.J., Blair, I.A., de Mey, C., and MacDermot, J. 1983. Epoprostenol (prostacyclin, $\mathrm{PGI}_{2}$ ) binding and activation of adenylate cyclase in platelets of diabetic and control subjects. Br. J. Clin. Pharmacol. 15: 77-81.

Shimoni, Y., Firek, L., Severson, D., and Giles, W. 1994. Shortterm diabetes alters $\mathrm{K}^{+}$currents in rat ventricular myocytes. Circ. Res. 74: 620-628.

Shindo, H., Tawata, M., and Onaya, T. 1993. Reduction of cyclic AMP in the sciatic nerve of rats made diabetic with streptozotocin and the mechanism involved. J. Endocrinol. 136: 431-438.

Takiguchi, Y., Satoh, N., Hashimoto, H., and Nakashima, M. 1989. Reversal effect of thyroxine on altered vascular reactivity in diabetic rats. J. Cardiovasc. Pharmacol. 13: 520-524.

Tomlinson, K.C., Gardiner, S.M., and Bennett, T. 1989. Diabetes mellitus in Brattleboro rats: cardiovascular, fluid, and electrolyte status. Am. J. Physiol. 256: R1279-R1285.

Tomlinson, K.C., Gardiner, S.M., Hebden, R.A., and Bennett, T. 1992. Functional consequences of streptozotocin-induced diabetes mellitus, with particular reference to the cardiovascular system. Pharmacol. Rev. 44: 103-150.

Tooke, J.E. 1989. Microcirculation and diabetes. Br. Med. Bull. 45: 206-223.

Tsuura, Y., Ishida, H., Okamoto, Y., Tsuji, K., Kurose, T., Horie, M., Imura, H., Okada, Y., and Seino, Y. 1992. Impaired glucose sensitivity of ATP-sensitive $\mathrm{K}^{+}$channels in pancreatic beta-cells in streptozotocin-induced NIDDM rats. Diabetes, 41: 861-865. 